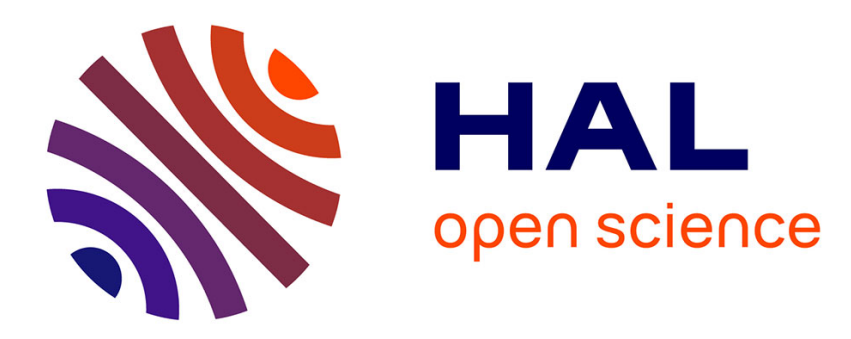

\title{
Dynamic compressive behaviour of ceramics under lateral confinement
}

W. M. Chen, G. Ravichandran

\section{To cite this version:}

W. M. Chen, G. Ravichandran. Dynamic compressive behaviour of ceramics under lateral confinement. Journal de Physique IV Proceedings, 1994, 04 (C8), pp.C8-177-C8-182. 10.1051/jp4:1994825 . jpa00253380

\section{HAL Id: jpa-00253380 https://hal.science/jpa-00253380}

Submitted on 1 Jan 1994

HAL is a multi-disciplinary open access archive for the deposit and dissemination of scientific research documents, whether they are published or not. The documents may come from teaching and research institutions in France or abroad, or from public or private research centers.
L'archive ouverte pluridisciplinaire HAL, est destinée au dépôt et à la diffusion de documents scientifiques de niveau recherche, publiés ou non, émanant des établissements d'enseignement et de recherche français ou étrangers, des laboratoires publics ou privés. 


\title{
Dynamic compressive behaviour of ceramics under lateral confinement
}

\author{
W. Chen and G. Ravichandran \\ Graduate Aeronautical Laboratories, 105-50 California Institute of Technology, Pasadena, \\ California 91125, U.S.A.
}

\begin{abstract}
Résumé: Une nouvelle technique expérimentale est proposée pour le confinement latéral d'éprouvettes sollicitées dynamiquement en compression uniaxiale à vitesse de déformation élevée. Une brève description de cette technique ainsi que certains résultats préliminaires sont présentés. Ces derniers montrent que le confinement latéral augmente la résistance à l'impact des verres céramiques fragiles comparativement aux résultats obtenus sans confinement. $\mathrm{La}$ propension de la céramique à la fragmentation est également supprimée lors du test avec confinement. Enfin, la relation contrainte-déformation de ces céramiques présente des caractéristiques inélastiques quand le matériau est confiné latéralement.
\end{abstract}

\begin{abstract}
A new experimental technique for imposing lateral confinement on specimens subjected to high-strain-rate uniaxial compression is being developed. A brief description of the experimental technique, as well as some preliminary experimental results of the technique are presented in this paper. The results show that under lateral confinement, the impact strength of a brittle glass ceramic increases as compared to its unconfined dynamic compressive failure strength. It is also observed that the propensity for the ceramic to fragment is suppressed by lateral confinement. Furthermore, the ceramic exhibits some inelasticity in the stress-strain behaviour in the presence of lateral confinement.
\end{abstract}

\section{INTRODUCTION}

Dynamic compressive failure strength is an important mechanical property that determines the suitability of ceramic materials in various applications. In brittle materials, the failure strength has been predicted to increase even under moderate amounts of lateral confinement $[1,2]$. This increase has been observed experimentally on rocks and ceramics under static confinement and quasi-static loading conditions [1,2,3]. Experimental 
techniques are to be developed which will allow the exploration of dynamic behaviour of brittle materials under multiaxial loading conditions. The experimental techniques currently available to test ceramics under dynamic loading conditions are those which impose uniaxial stress in the specimen, commonly, uniaxial compression [4]. In this paper, we present a modified experimental technique based on split Hopkinson (Kolsky) pressure bar (SHPB) with momentum trapping capability [8].

\section{EXPERIMENTAL SET UP}

\subsection{Split Hopkinson Pressure Bar}

Split Hopkinson pressure bar technique is a well established experimental method for high strain rate testing of ductile metals under uniaxial stress conditions $[5,6]$. A schematic of the basic SHPB is shown in Fig. 1. Details of this experimental technique can be found elsewhere $[5,6]$. One-dimensional calculations by Kolsky [7] show that the axial strain rate in the specimen can be estimated using

$$
\dot{\varepsilon}(\mathrm{t})=-\frac{2 \mathrm{c}_{0}}{1} \varepsilon_{\mathrm{r}}(\mathrm{t})
$$

where 1 is the original length of the specimen, $\varepsilon_{\mathrm{r}}$ is the time-dependent reflected strain in the incident bar, and $c_{0}$ is the elastic longitudinal bar wave velocity in the incident bar. The axial stress in the specimen is calculated by

$$
\sigma(t)=\frac{A_{0}}{A_{s}} E \varepsilon_{t}(t)
$$

where $A_{0}$ and $A_{s}$ are the cross-sectional area of the transmission bar and the specimen respectively, $E$ is the Young's modulus of the transmission bar material, and $\varepsilon_{t}$ is the timedependent axial strain in the transmission bar.

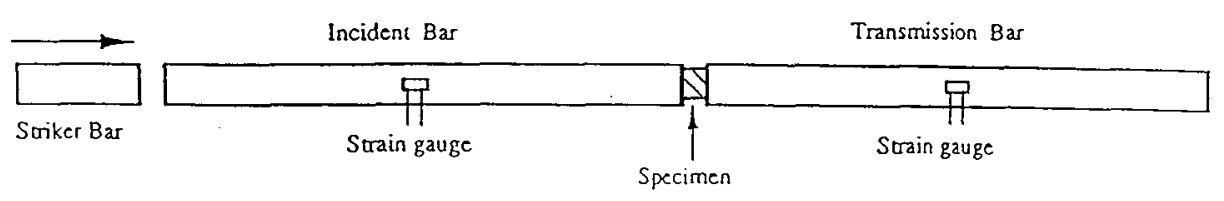

Fig. 1 Schematic of the split Hopkinson pressure bar system

\subsection{Lateral Confinement}

The confining pressure can be applied by various approaches, for example, by using electro-magnetic force [9], by hydrostatic pressure [3] or by mechanical means. In this paper, we present the mechanical approach where the confining pressure is achieved by installing a shrink fit sleeve on the lateral surface of the cylindrical specimen as shown in Fig. 2. The shrinkage of the sleeve provides confinement pressure on the lateral surface of the specimen. In the experiments reported in this paper, thin walled sleeves were used. The confining pressure produced by the sleeve can then be estimated by the thin walled cylinder assumption: 


$$
\mathrm{p}=\frac{\sigma_{\mathrm{y}} \mathrm{t}}{\mathrm{r}}
$$

where $p$ is confining pressure on the lateral surface of the specimen, $\sigma_{y}$ is the quasi-static yield stress of the sleeve material, $t$ is the sleeve wall thickness, and $r$ is specimen radius. Different sleeve material (different $\sigma_{y}$ ) can provide different confining pressure as desired.

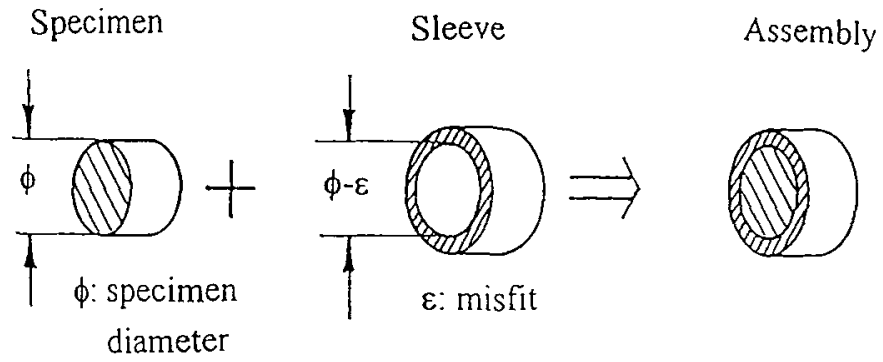

Fig. 2 Specimen/sleeve assembly

The advantage of the confining sleeve method is its cost-effectiveness and there is no need to modify the SHPB facility. Also, the plastically deformed sleeve will hold the tested specimen together for further failure mode investigation, even though the brittle specimen itself may have fragmented during the axial impact loading.

\subsection{Data Interpretation}

With the addition of the confining sleeve on the specimen, Eqn. (2) can no longer be used to calculate axial stress in the ceramic specimen. Instead, the following formula should be used:

$$
\sigma(t)=\frac{A_{0}}{A_{s}} E \varepsilon_{t}(t)-\frac{A_{c}}{A_{s}} \sigma_{c}(\varepsilon, \dot{\varepsilon})
$$

where $A_{c}$ is the cross-sectional area of the sleeve, and $\sigma_{c}$ is the axial stress in the sleeve. The value of $\sigma_{c}$ is obtained from a dynamic uniaxial compressive stress-strain curve, which is obtained from the test on the sleeve material at the same strain rate as the specimen/sleeve assembly. On each specimen/sleeve assembly, an axial strain gauge is glued on the outer surface of the sleeve to record the actual strain profile the assembly experiences in the loading process [10]. In the high strength ceramic testing, hard inserts should be placed between the end faces of the specimen and the bars to keep these interfaces flat [11]. 


\section{RESULTS AND DISCUSSION}

To check the feasibility of the experimental technique, a previously investigated machinable glass ceramic, macor[10], is used as a model material in the preliminary experiments. The mechanical properties of macor are listed in Table 1. Five different sleeve materials are used. The materials and their quasi-static yield stresses are listed in Table 2. The specimens are $8.10 \mathrm{~mm}$ in diameter and $8.25 \mathrm{~mm}$ in length. The sleeve wall thickness is $0.73 \mathrm{~mm}$. The end surfaces of the specimen/sleeve assembly are ground to make the end faces flat and parallel, and then polished to remove any surface damage from the grinding. The experiments were performed at projectile velocities of $26 \mathrm{~m} / \mathrm{s}$ and 37 $\mathrm{m} / \mathrm{s}$ respectively. A pulse shaper is placed between the incident and striker bars [10].

Table 1. Specimen material

\begin{tabular}{|l|l|}
\hline Mass Density & $2520 \mathrm{~kg} / \mathrm{m} 3$ \\
\hline Young's Modulus & $64.1 \mathrm{GPa}$ \\
\hline Poisson's Ratio & 0.26 \\
\hline $\begin{array}{l}\text { Quasi-static } \\
\text { Compressive } \\
\text { Strength }\end{array}$ & $345 \mathrm{MPa}$ \\
\hline
\end{tabular}

Table 2. Sleeve materials

\begin{tabular}{|c|c|}
\hline Material & Yield Stress, MPa \\
\hline PMMA & 80 \\
\hline Copper & 264 \\
\hline Al-6061-T6 & 275 \\
\hline Brass & 327 \\
\hline Al-2024-T3 & 345 \\
\hline
\end{tabular}

\subsection{Failure Mode}

Figure 3 shows the faces of the recovered specimens (which were in contact with the incident bar) after being tested at striker bar velocity of $37 \mathrm{~m} / \mathrm{s}$. From left, they are the specimens without confinement, with a nylon sleeve, with a copper sleeve, and with a brass sleeve. The specimen from the experiment with no confinement was completely fragmented as shown in Fig. 4, even though it was loaded only once by the momentum trapping SHPB. With small confinement pressure (10 MPa by nylon sleeve), the specimen also fragmented, but the fragment sizes are larger as can be seen from the crack density on the surface. As the confining pressure was increased to $48 \mathrm{MPa}$ (copper sleeve), the crack density was further reduced. When the lateral pressure was increased to (brass sleeve) 59 $\mathrm{MPa}$, few cracks can be seen on this surface, even though the permanent axial strain measures $12.8 \%$ on the recovered sample. Cracks are visible on the other end face of the same specimen. It seems that the propensity for crack growth is suppressed by the lateral confinement pressure.

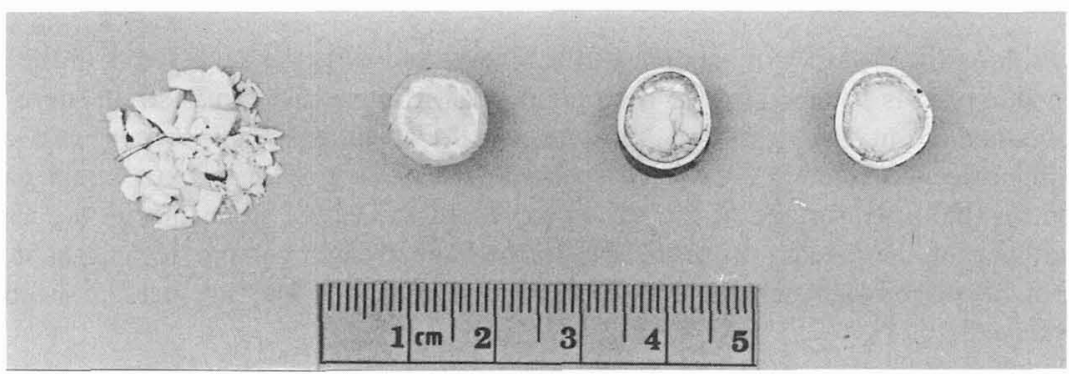

Fig. 3 Recovered specimens 


\subsection{Constitutive Behaviour}

Figure 4 shows the stress-strain curves of the specimens without confinement and with confinement by brass sleeve respectively. The specimens were tested at projectile velocity of $37 \mathrm{~m} / \mathrm{s}$. As shown in Fig. 4, the stress-strain relation for the unconfined specimen is nearly linear until close to catastrophic failure which is typical for brittle materials under uniaxial loading. With lateral confinement, the initial part of the stress-strain curve of the specimen is close to the uniaxial linear behaviour except the Young's modulus is higher. However, after the axial stress reaches about $350 \mathrm{MPa}$ (which corresponds to an axial strain of $0.44 \%$ ), the tangent modulus drops to about $22 \mathrm{GPa}$ and further decreases at larger axial strains. Figure 4 clearly shows the inelastic part of the constitutive relation of a confined ceramic specimen under axial loading. With the presence of lateral confinement, the stress-strain relation of the ceramic material cannot be treated as a constant ratio until failure which characterizes most brittle ceramic materials under uniaxial compression conditions.

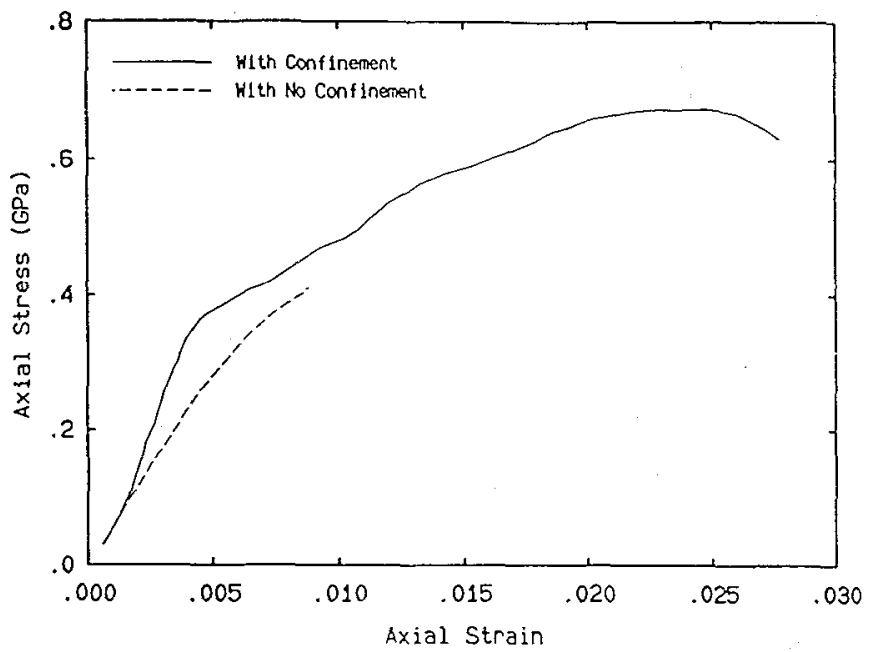

Fig. 4 Axial stress-strain response with and without confinement

\subsection{The Role of Confinement}

In the pressure range and the small amount of specimens we used in our experiments, the impact strength increases from $0.45 \mathrm{GPa}$ to $0.72 \mathrm{GPa}$ as the lateral confining pressure increases from zero to about $60 \mathrm{MPa}$.

\section{CONCLUSIONS}

A new experimental technique capable of applying dynamic uniaxial compression with lateral confinement to a ceramic specimen is being developed. During the experiment, the specimen is subjected to a known loading history. Microscopic observations on the recovered sample can thus be related to the macroscopic behaviour of the material. 
Preliminary experiments show that for a moderate confining pressure range of $10 \mathrm{MPa}$ $\sim 60 \mathrm{MPa}$, there is an apparent increase in impact strength and inelastic behaviour for machinable glass ceramic, macor, as compared to the unconfined case. Recovered samples show that under confining pressure, the failure mode (damage) changes considerably, from complete fragmentation to little or no damage in the sample.

\section{ACKNOWLEDGMENTS}

This research is been supported by the U. S. Army Research Office under grant No. DAALO3-02-G-0192 to the California Institute of Technology. The authors would like to thank Dr. Michael J. Forestall of the Sandia National Laboratories for his suggestions regarding the confinement experiments.

\section{REFERENCES}

[1] Horii, H. and Nemat-Nasser, S., Phil. Trans. Roy. Soc. London, 319 (1986) 337-374.

[2] Ashby, M. F. and Sammis, C. G., Pure Appl. Geophys., 133 (1990) 489-521.

[3] Arrowood, R. and Lankford, J., J. Mat. Sci., 22 (1987) 3737-3744.

[4] Lankford, J., Mat. Sci. and Eng., A107 (1989) 261-268.

[5] Lindholm, U.S., J. Mech. Phys. Solids, Vol. 12, (1964) 317-335.

[6] Follansbee, P., Metals Handbook, Vol, 8, (9th ed., American Society for Metals, 1985) pp. 198-217.

[7] Kolsky, H., Proc. Roy. Soc. London, 1949, Vol. B62 (1949) 676-700.

[8] Nemat-Nasser, S., Isaacs, J. B. and Starrett, J.E., Proc. R. Soc. London, A435 (1991) 371-391.

[9] Chen, W. and Ravichandran, G., "Dynamic Behaviour of ceramics under multiaxial compression," The Army Symposium on Solid Mechanics, Plymouth, MA, (eds: F.

Bartlett, S. C. Chou, K. Iyer and T. W. Wright, Army Research Laboratories) (1993).

[10] Ravichandran, G., and Chen, W., "Dynamic Failure of Brittle material under uniaxial compression," Experiments in Micromechanics of Fracture Resistant Materials, AMD130, ASME WAM, Atlanta 1-6 December 1991 (ed: K. S. Kim) pp. 85-90.

[11] Chen, W., Subhash, G. and Ravichandran, G., "Evaluation of ceramic specimen geometries used in the split Hopkinson pressure bar," SM Report \# 94-2, Graduate Aeronautical Laboratories, California Institute of Technology, Pasadena, California (1994). 